\section{Influence of Abutment Collar Height and Implant Length on Stress Distribution in Single Crowns}

\author{
Dimorvan Bordin ${ }^{1}$, Altair Antoninha Del Bel Cury²@, Fernanda Faot ${ }^{3} @$
}

\begin{abstract}
This in silico study evaluated the influence of the abutment collar height and implants length on the biomechanical behavior of morse taper single dental implants with different crown-to-implant ratio. Six virtual models were constructed (S11, M11, L11, S13, M13 and $\mathrm{L} 13)$ by combining short ( $\mathrm{S}: 2.5 \mathrm{~mm})$, medium $(\mathrm{M}: 3.5 \mathrm{~mm})$ or long (L: $4.5 \mathrm{~mm})$ abutment collar heights with different implant lengths (11 or 13-mm). An upper central incisor of $11-\mathrm{mm}$ height was constructed on top of each abutment. Each set was positioned in a virtual bone model and exported to analyze mathematically. A 0.60-mm mesh was created after convergence analysis and a $49 \mathrm{~N}$ load was applied to the cingulum of the crown at an angle of $45^{\circ}$. Load-generated stress distribution was analyzed in the prosthetic components according to von Mises stress criteria ( $\sigma \mathrm{vM})$ and in the cortical and cancellous bone by means of shear stress (cmax). The use of longer collar abutments (L11) increased the stress on the abutment by $250 \%$ and resulted in $40 \%$ higher stresses on the screw and 92\% higher cortical shear stresses compared to short collared abutments (S11). Increasing the implant length produced a slight stress reduction on cortical bone. Cancellous bone was not affected by the crown-to-implant ratio. Longer abutment collars concentrate stresses at the implant level and cortical bone by increasing the crown-to-implant ratio.
\end{abstract}

'UNG - Universidade de Guarulhos, Guarulhos, SP, Brazil

${ }^{2}$ Piracicaba Dental School, UNICAMP - Universidade Estadual de Campinas, Piracicaba, SP, Brazil ${ }^{2} \mathrm{School}$ of Dentistry, UFPEL - Universidade Federal de Pelotas, Pelotas, RS, Brazil

Correspondence: Fernanda Faot, Rua Gonçalves Chaves, 457, 96015-560 Pelotas, RS, Brasil. Tel: +55-53-3260-2801. e-mail: fernanda.faot@gmail.com

Key Words: dental implants; prosthetic abutments, finite element analysis, single dental implants, anterior single crowns

\section{Introduction}

The distance between the top of marginal peri-implant soft tissue and the implant platform determines the collar height of the prosthetic abutment that is needed for an adequate biological width and emergence profile of the crown (1). To guarantee esthetically pleasing results, abutment selection according to gingival height index depends on two main factors: i) the depth of the gingival sulcus guided by the ocluso-cervical gingival height and ii) the restorative vertical space (2). Patients with deeper gingival sulcus usually need longer abutment collars than patients with shallow ones. The minimum collar abutment height required to guarantee appropriate esthetics should be at least $1 \mathrm{~mm}$ below the gingival margin. Although higher abutments would reduce the peri-implant marginal bone loss due to the increased crown to bone distance (3), those abutments also increase the crown-to-implant ratio (C:I) by increasing the collar length, which in turn influences the implant's biomechanical behavior in a way that may increase marginal bone loss.

In a biomechanical scenario, the fulcrum in an implantsupported single crown is located at the implant platform level. Consequently, higher abutments collars increase the lever effect during loading (1-3). Furthermore, assuming the height of abutment from implant platform to the top of abutment, including abutment collar, an increase in the collar height might result in an increase in the vertical cantilever (1). This phenomenon can be intensified in the anterior region where the set is submitted to oblique loading as a result of chewing (4), especially on abutments connected to Morse taper implants that present a narrow structure at the implant-abutment interface. Previous studies showed that increasing the crown height poses a risk for rehabilitations, as the bone stress increases by about 20\% for each $\mathrm{mm}$ of increased crown height $(5,6)$.

Using implants with higher length could increase the resistance arm and improve the stress distribution $(7,8)$. According to Rubo et al. (7), increasing implants length from 10 to $13 \mathrm{~mm}$ contributes a decrease of about 14\% in total stress. Although longer implants do not influence the abutment deflection, they may better dissipate the stresses arising from the masticatory forces and reduce biological and technical complications due to unfavorable C:I ratio $(1,9)$.

To clarify the influence of the abutment collar height on stress distribution, this study evaluates the biomechanical behavior of single Moser taper implants connected to abutments of different collar heights.

\section{Material and Methods Experimental Design}

Six three-dimensional models of a single-crown implantsupported restoration were constructed according to implant length (11 or 13-mm) and abutment collar height: short ( $\mathrm{S}$, 
2.5-mm), medium ( $\mathrm{M}, 3.5-\mathrm{mm})$ and long ( $\mathrm{L}, 4.5-\mathrm{mm})$ : S11, $\mathrm{M} 11, \mathrm{~L} 11, \mathrm{~S} 13, \mathrm{M} 13$ and $\mathrm{L} 13$ respectively. All models were loaded with $49 \mathrm{~N}$ at $45^{\circ}$ to the cingulum of the crown (10). The data were evaluated using the maximum shear stress (عmax) for the cortical and cancellous bone and the von Mises stress ( $\sigma \mathrm{VM})$ for the implant, abutment and screw.

\section{Model Construction}

The anterior region of an edentulous maxilla was reproduced using SolidWorks $2013^{\circledast}$ (SolidWorks $^{\circledR}$ Corp, Waltham, MA, USA) based on digital computed tomography images. The bone model was composed of cancellous bone surrounded by $1.5 \mathrm{~mm}$ of cortical bone that corresponds to type III bone quality (11). All 3D CAD models in this study were designed to standardize the studied factors (abutment collar height and implant length). The implant was inserted at $1 \mathrm{~mm}$ bellow bone level. A single cementedretained restoration in the maxillary anterior region was simulated, supported by a Morse taper implant (4.1-mm platform) with two different lengths (11 or $13-\mathrm{mm}$ ). An anatomic abutment of the central incisor and its respective screw were modeled with different collar length: $2.5 \mathrm{~mm}$ (short - S), $3.5 \mathrm{~mm}$ (medium - M) and $4.5 \mathrm{~mm}$ (large - L). A 11-mm high central incisor crown was reproduced based on human extracted teeth microtomographic images and cemented to the abutment with a $50-\mu \mathrm{m}$ thick layer of resin cement. A representative image of $\mathrm{C}: \mathrm{I}$ ratios determination and bending moment can be seen in Figure 1, as well as, the 6 models created to be tested. The C:I ratios were calculated by dividing the total crown length (11-mm + abutment collar height) by the respective implant lengths: $1.23,1.32,1.41,1.04,1.12$ and 1.19 for the S11, M11, L11, S13, M13, and L13 models, respectively. The models were exported to Ansys Workbench 14.0 FEA software (Swanson Analysis Systems, Inc. Houston, PA, USA) to perform the numerical analysis.

\section{Numeric Analysis}

The mesh was achieved using a $0.6 \mathrm{~mm}$ tetrahedral elements configuration defined after a 5\% tolerance convergence analysis. The material properties of implants, abutments and screws were assumed to be as titanium. On the other hand, the prosthetic crown was considered as ceramic (lithium disilicate) cement-retained by a resin luting cement. The Young's modulus and Poison ratio used were listed in the Table 1 (12-14). The implant was inserted at $1 \mathrm{~mm}$ bellow bone level according to manufactures instruction. All materials were considered homogenous, isotropic and linearly elastic.

The boundary conditions were defined by fixing both lateral exterior surfaces of the bone segment. A load of $49 \mathrm{~N}$ was applied in the palatal region of the prosthetic crown angulated at $45^{\circ}$ with the long-axis of the implant (10). The values of maximum shear stress (عmax) for cortical and cancellous bone and von Mises stress ( $\sigma \mathrm{vM}$ ) for implants and prosthetic components were obtained. The difference percentage were calculated and compared among the models.

\section{Results}

The maximum shear stress for cortical and cancellous bone and maximum von Mises stress for the implant and prosthetic components are described in Table 2. The percentage differences in function of the abutment's collar length and implant length are described in Table 3. For the $11 \mathrm{~mm}$ implant, a higher $\mathrm{C}: \mathrm{I}$ ratio $(\mathrm{S} 11 \rightarrow \mathrm{L} 11)$ increased the stress in the abutment, screw, implant and cortical bone. The prosthetic abutments were the most impaired piece of the joint, and the longest abutments showed an increase of 250\% compared to the shortest ones (Small: 204-MPa; Long: 712-MPa). Higher implant lengths $(13 \mathrm{~mm}$ ) resulted in a negligible stress decrease in the abutments $(-2 \%)$.

Longer abutments recorded $40 \%$ higher stresses in the screw compared to short abutments for both implants length (S11 and S13: 99-MPa; L11 and L13: 139-MPa). The shear stress at cortical bone was higher when the longer abutment was used, increasing $75 \%$ in the case of the $11-\mathrm{mm}$ implant $(\mathrm{S} 11 \rightarrow \mathrm{L} 11)$ and $92 \%$ when the 13$\mathrm{mm}$ implant was used (S13 $\rightarrow \mathrm{L} 13)$. The cortical bone was negative affected by the higher $\mathrm{C}: \mathrm{I}$ ratio for both implant sizes. Cancellous bone was not affected by the crown-toimplant ratio. Qualitative stress distribution patterns and maximum peak concentration at the regions of interest are shown in Figure 2.

\section{Discussion}

The C:I ratio can be responsible for biological or mechanical damage, as the stress tolerance limits are still not accurately known. This study evaluated the combined influence of abutment height and implant length on the biomechanical behavior of single-implants during restoration. Therefore, three-dimensional finite element analysis was used to predict the biomechanical

Table 1. Material properties used for the numerical simulation

\begin{tabular}{lccc}
\hline Material & $\begin{array}{c}\text { Young's } \\
\text { modulus (GPa) }\end{array}$ & $\begin{array}{c}\text { Poison } \\
\text { ratio }\end{array}$ & Reference \\
\hline Cortical bone & 13.6 & 0.26 & $(12)$ \\
Cancellous bone & 1.36 & 0.31 & $(12)$ \\
Ti-6Al-4V & 110 & 0.35 & $(12)$ \\
Lithium disilicate & 96 & 0.23 & $(13)$ \\
Resin luting cement & 18.3 & 0.30 & $(14)$ \\
\hline
\end{tabular}


behavior of single dental implants with various dimensions during rehabilitation. The models were assumed to be homogeneous, isotropic, and linearly elastic. The bone and prosthetic crown were constructed based on tomography images and the implant, abutment, and screw were based on commercially available pieces that contribute to improve the accuracy of the models. In addition, a surrounding bone was constructed as an independent piece in order to obtain the specific stress of the peri-implant bone.

The obtained results indicated that the abutment was the most impaired part of the implant during restoration, especially for a high C:I ratio of 1.41. The stress increased by about $250 \%$ when a higher collar abutment $(4.5 \mathrm{~mm})$ was associated with an 11-mm implant (L11). These results corroborate those of Machado et al. (15), who observed the predominance of abutment failure in vitro for morse taper implants that can be attributed to the large contact area between implants and abutments. The reliability of the set is challenged by the thick cervical abutments wall bended to implants platform during oblique loading (1516). Furthermore, a recent systematic review (17) proposed that a C:I ratio higher than 1.46 can be related to prosthetic failure and represents a risk of abutment fracture.

The prosthetic's screws were negative affected by higher C:I ratios, with stress increases up to $40 \%$, regardless of the implant length. Screw loosening is considered the most important reason for prosthetic failure during rehabilitation, especially for the external hexagon connections $(18,19)$. In cases using internal connections, these failures are more associated with twopiece abutments than solid abutments because they boltboltare thicker, with less material that can dissipate the strain energy from the loading during chewing. A systematic review by Gracis et al. (20) pointed out interesting clinical outcomes that can be analyzed during the abutment selection to assess its failure potential: i) the incidence of fracture of metal-based and zirconia-based abutments and that of abutment screws does not seem to be influenced by the type of connection; ii) loosening of abutment screws was still the most frequently occurring technical complication and seemed to be influenced by the type of connection, more loose screws were reported for externally connected implant systems; iii) proper preload may decrease the incidence of such a complication.

The relationship between occlusal forces on oral implants and the surrounding bone can be compromised by overloading resulting in biological complications or even osseointegration failure (21). The response to an increased mechanical stress below a certain threshold will be a strengthening of the bone by increasing the bone density or apposition of
Figure 1. A) Anterior region of edentulous maxilla reproduced using SolidWorks $2013^{\varpi}$ (SolidWorks ${ }^{\varpi}$ Corp, Waltham, MA, USA) based on digital computed tomography images. Models composition according to the abutments collar height showing the Crown:Implant ratio in the 11-mm (B) the 13mm (C) dental implants. 
bone. On the other hand, fatigue micro-damage resulting in bone resorption may be the result of mechanical stress beyond this threshold (22). The highest cortical shear stresses of $39.93 \mathrm{MPa}$ were observed in the L11 models.
The latter is 75\% higher than the corresponding stresses in the S11 models. The region with the maximum peak stress was restricted to the peri-implant bone around the first implant threads. This corroborates the results from

Table 3. Relative stress differences (\%) in function of abutment height (Small, Medium and Long) and implant length (11 and 13-mm)

\begin{tabular}{|c|c|c|c|c|c|c|c|c|c|}
\hline \multirow{2}{*}{$\begin{array}{l}\text { Regions } \\
\text { of interest }\end{array}$} & \multicolumn{6}{|c|}{$\begin{array}{l}\text { Difference between } \\
\text { abutment heights (\%) }\end{array}$} & \multicolumn{3}{|c|}{$\begin{array}{l}\text { Difference between } \\
\text { implant lenghts }(\%)\end{array}$} \\
\hline & $\mathrm{M}_{11}-\mathrm{S}_{11}$ & $\mathrm{~L}_{11}-\mathrm{M}_{11}$ & $\mathrm{~L}_{11}-\mathrm{S}_{11}$ & $\mathrm{M}_{13}-\mathrm{S}_{13}$ & $\mathrm{~L}_{13}-\mathrm{M}_{13}$ & $\mathrm{~L}_{13}-\mathrm{S}_{13}$ & $\mathrm{~S}_{13^{-}}-\mathrm{S}_{11}$ & $\mathrm{M}_{13}-\mathrm{M}_{11}$ & $\mathrm{~L}_{13-} \mathrm{L}_{11}$ \\
\hline Screw & $11 \%$ & $26 \%$ & $40 \%$ & $11 \%$ & $26 \%$ & $40 \%$ & $0 \%$ & $0 \%$ & $0 \%$ \\
\hline Implant & $21 \%$ & $6 \%$ & $29 \%$ & $24 \%$ & $-7 \%$ & $15 \%$ & $0 \%$ & $2 \%$ & $-11 \%$ \\
\hline Abutment & $44 \%$ & $142 \%$ & $250 \%$ & $46 \%$ & $135 \%$ & $243 \%$ & $0 \%$ & $1 \%$ & $-2 \%$ \\
\hline Cortical bone & $6 \%$ & $65 \%$ & $75 \%$ & $18 \%$ & $63 \%$ & $92 \%$ & $-15 \%$ & $-5 \%$ & $-7 \%$ \\
\hline Cancellous bone & $-11 \%$ & $23 \%$ & $10 \%$ & $11 \%$ & $3 \%$ & $14 \%$ & -5.5 & $18 \%$ & $0 \%$ \\
\hline
\end{tabular}

(D)

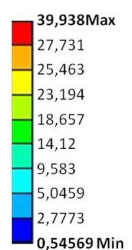

E


$\mathrm{S}_{11}$

$\mathrm{S}_{11}$

$\mathrm{S}_{13}$
B


$M_{13}$

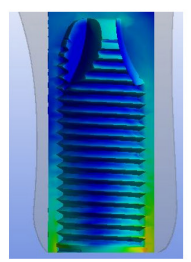

$M_{11}$



$\mathrm{L}_{11}$


128,91

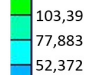

52,372

1,3492 Min



$\mathrm{S}_{13}$
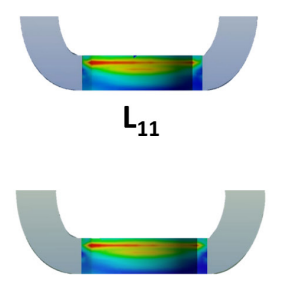

$\mathrm{L}_{13}$



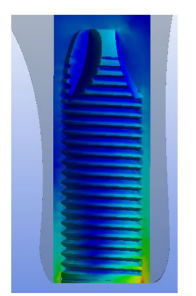

$\mathrm{S}_{13}$

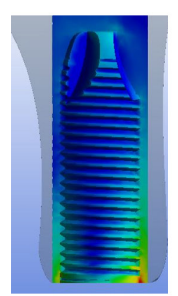

$M_{13}$



$\mathrm{L}_{13}$

Figure 2. Maximum stress concentration at the regions of interest for all experimental groups. A: Screws. B: Abutments. C: Implants. D: Cortical bone. E: Cancellous bone. 
Rieger et al. (23), who demonstrated that high stress levels induced during bending are concentrated around the neck and are dissipated via the apex.

To test whether the biomechanical behavior could be further improved, longer implants of $13 \mathrm{~mm}$ were selected. However, a stress reduction of only 15\% in the cortical bone was observed, indicating that higher implants lengths are not able to decrease the stress significantly. Recent studies suggested that implant diameter should be more important than the implants length to control bone overloading since wide implants have a larger bone-implant contact, especially in the cervical region, the stress is concentrated near the first implant's threads in contact with cortical bone $(11,24,25)$.The bone stresses obtained in this study were below the physiologic limits described in the literature for the elastic limit of the human cortical bone (60 MPa) (26). However, it is until unclear the correlation between bone adaptive capacity to distribute stress without biological damages (27), since experimental studies have shown different biomechanical behaviors when oblique forces are involved leading an increased bone response $(15,17,26)$.

Although, a recent study (28) suggested that shorter abutment height is associated with greater marginal $\vec{z}$ bone loss in cement-retained protheses, our in silico ¿ study prosthetic abutments with shorter collar heights showed a better biomechanical behavior for all prosthetic components and cortical bone, irrespective of the implant height. Shorter abutments allow to select abutments with increased body height, increasing the crown retention and improving the stability of the crown-abutment-implant connection and the accessibility during impression procedures $(1,20)$. Moreover, implants with higher C:I ratios positively affect the peri-implant marginal bone level (MBL): within the $C: I$ range of $0.6-2.36$, higher $C: I$ ratios negatively correlate with the peri-implant MBL (9). Clinically, these implants can still achieve good short- to medium-term survival rates, as long as the occlusion and parafunctional habits are controlled $(3,9,29)$. In addition, the placement of platform-switched implants and the use of long abutments connecting cemented crowns to implants would provide greater height for biologic width reestablishment, allow easier removal of excess cement from soft tissue and reducing bacteria-induced inflammation, consequently preventing progression of marginal bone loss in cement-retained restorations (28).

More studies are still required to investigate the stiffness of the system to provide a displacement map of the different structures. This would be needed to fully characterize the potential deformation of the implantabutment system. Different experimental parameters can also be considered in future modeling studies, such as bone type, positions in the arch, partial and full arch bridge prostheses, prosthetic connections and loading directions. Higher crown-to-implant ratios in long-collar abutments can negatively affect the biomechanical behavior of single crowns supported by morse taper implants, and the highest stresses are located in the prosthetic abutment. Increasing the crown length has a small positive effect on the cortical bone stress values. The stress in the cancellous bone showed no relation with $\mathrm{C}: \mathrm{I}$ ratios or implant lengths.

\section{Resumo}

Este estudo avaliou a influência da altura da porção transmucosa do pilar protético com junção cone morse e do comprimento dos implantes no comportamento biomecânico coroas unitárias com diferentes proporção coroa-implante. Seis modelos virtuais (S11, M11, L11, S13, M13 e L13) foram construídos combinando pilares protéticos com transmucoso considerado: curto ( $\mathrm{S}: 2,5 \mathrm{~mm}$ ), médio ( $\mathrm{M}: 3,5 \mathrm{~mm}$ ) ou longo (L: 4,5 mm) com diferentes comprimentos de implantes (11 ou $13 \mathrm{~mm}$ ). Um incisivo central superior de $11 \mathrm{~mm}$ de altura foi construído para cada pilar. Cada conjunto foi posicionado em um modelo de osso virtual e exportado para análise matemática. Uma malha de $0,60 \mathrm{~mm}$ foi criada após análise de convergência e uma carga de $49 \mathrm{~N}$ foi aplicada ao cíngulo da coroa em um ângulo de $45^{\circ}$. A distribuição de estresse gerada por carga foi analisada nos componentes protéticos de acordo com o critério de tensão de von Mises ( $\sigma \mathrm{VM})$ e no osso cortical e medular por meio da tensão de cisalhamento (zmax). 0 uso de pilares com porção transmucosa mais longa (L11) aumentou a tensão no pilar protético em $250 \%$, e resultou em tensões 40\% maiores no parafuso e $92 \%$ no osso cortical em relação aos pilares com transmucoso curto (S11). 0 aumento do comprimento do implante produziu uma ligeira redução da tensão de cisalhamento no osso cortical. 0 osso medular não foi afetado pela relação coroa-implante. Pilares protéticos com porção transmucosa mais longa concentram tensões no implante e no osso cortical, quando a proporção coroa-implante é aumentada.

\section{Acknowledgements}

This work was supported by CAPES through a doctoral fellowship to the first author (Process 33003033008P8).

\section{References}

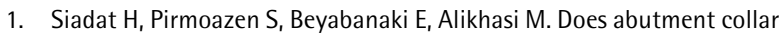
length affect abutment screw loosening after cyclic loading? J Oral Implantol 2015;41:346-351.

2. Abichandani SJ, Nadiger R, Kavlekar AS. Abutment selection, designing, and its influence on the emergence profile: A comprehensive review. Eur J Prosthodont 2013;1:1-10.

3. Galindo-Moreno P, León-Cano A, Ortega-Oller I, Monje A, Suárez F, ÓValle F. Prosthetic Abutment Height is a Key Factor in Peri-implant Marginal Bone Loss. J Dent Res 2014;93:80-85.

4. Grossmann Y, Sadan A. The prosthodontic concept of crown-to-root ratio: a review of the literature. J Prosthet Dent 2005;93:559-562.

5. Bidez MW, Misch CE. Force transfer in implant dentistry: basic concepts and principles. J Oral Implantol 1992;18:264-274.

6. Bidez MW, Misch CE. Issues in bone mechanics related to oral implants. Implant Dent 1992;1: 289-294.

7. Rubo JH, Capello Souza EA. Finite-element analysis of stress on dental implant prosthesis. Clin Implant Dent Relat Res 2010;12:105-113.

8. Borie $E$, Orsi IA, de Araujo CPR. The influence of the connection, length and diameter of an implant on bone biomechanics. Acta Odontol Scand 2015;73:321-329.

9. Garaicoa-Pazmino C, Suarez-Lopez del Amo F, Monje A, Catena A, Ortega-Oller I, Galindo-Moreno P, et al. Influence of crown/implant ratio on marginal bone loss: a systematic review. J Periodontol 2014;85:1214-1221 
10. Bordin D, Cavalcanti IMG, Jardim Pimentel M, Fortulan CA, Sotto-Maior BS, Del Bel Cury AA, et al. Biofilm and saliva affect the biomechanical behavior of dental implants. J Biomech 2015;48:997-1002.

11. Okumura N, Stegaroiu R, Kitamura E, Kurokawa K, Nomura S. Influence of maxillary cortical bone thickness, implant design and implant diameter on stress around implants: a three-dimensional finite element analysis. J Prosthodont Res 2010;54:133-142.

12. Cruz M, Wassall T, Toledo EM, da Silva Barra LP, Cruz S. Finite element stress analysis of dental prostheses supported by straight and angled implants. Int J Oral Maxillofac Implants 2009;24:391-403.

13. Albakry M, Guazzato $M$, Swain MV. Biaxial flexural strength, elastic moduli, and x-ray diffraction characterization of three pressable allceramic materials. J Prosthet Dent 2003;89:374-380.

14. Li L, Wang Z, Bai Z, Mao Y, Gao B, Xin H, et al. Three-dimensional finite element analysis of weakened roots restored with different cements in combination with titanium alloy posts. Chin Med J 2006;119:305-311.

15. Machado LS, Bonfante EA, Anchieta RB, Yamaguchi S, Coelho PG. Implant-abutment connection designs for anterior crowns: reliability and failure modes. Implant Dent 2013;22:540-545.

16. Schmitt CM, Nogueira-Filho G, Tenenbaum HC, Lai JY, Brito C, Döring $\mathrm{H}$, et al. Performance of conical abutment (Morse Taper) connection implants: A systematic review. J Biomed Mater Res Part A 2014;102:552-574.

17. Quaranta A, Piemontese M, Rappelli G, Sammartino G, Procaccini M. Technical and biological complications related to crown to implant ratio: a systematic review. Implant Dent 2014;23:180-187.

18. Kourtis S, Damanaki M, Kaitatzidou S, Kaitatzidou A, Roussou V. Loosening of the fixing screw in single implant crowns: predisposing factors, prevention and treatment options. J Esthet Restor Dent 2017;29:233-246.

19. Sakamoto K, Homma S, Takanashi T, Takemoto S, Furuya Y, Yoshinari $\mathrm{M}$, et al. Influence of eccentric cyclic loading on implant components: Comparison between external joint system and internal joint system. Dent Mater J 2016;35:929-937.

20. Gracis S, Michalakis K, Vigolo P, Vult von Steyern P, Zwahlen M, Sailer
I. Internal vs. external connections for abutments/reconstructions: a systematic review. Clin Oral Implants Res 2012;23:202-216.

21. Naert I, Duyck J, Vandamme K. Occlusal overload and bone/implant loss. Clin Oral Implants Res 2012;23:95-107.

22. Isidor F. Influence of forces on peri-implant bone. Clin Oral Implants Res 2006; 2:8-18.

23. Rieger MR, Mayberry $M$, Brose MO. Finite element analysis of six endosseous implants. J Prosthet Dent 1990;63:671-676.

24. Ortega-Oller I, Suarez $F$, Galindo-Moreno $P$, Torrecillas-Martinez $L$, Monje $A$, Catena $A$, et al. The influence of implant diameter on its survival: a meta-analysis based on prospective clinical trials. J Periodontol 2014;85:569-580.

25. Anitua E, Tapia R, Luzuriaga F, Orive G. Influence of implant length, diameter, and geometry on stress distribution: a finite element analysis. Int J Periodontics Restorative Dent 2010;30:89-95.

26. Papavasiliou G, Kamposiora P, Bayne SC, Felton DA. Three-dimensional finite element analysis of stress-distribution around single tooth implants as a function of bony support, prosthesis type, and loading during function. J Prosthet Dent 1996;76:633-640.

27. Kozlovsky A, Tal H, Laufer B-Z, Leshem R, Rohrer MD, Weinreb M, et al. Impact of implant overloading on the peri-implant bone in inflamed and non-inflamed peri-implant mucosa. Clin Oral Implants Res 2007;18:601-610.

28. Spinato S, Galindo-Moreno P, Bernardello F, Zaffe D. Minimum abutment height to eliminate bone loss: influence of implant neck design and platform switching. Int J Oral Maxillofac Implants 2018; 33:405-411.

29. Galindo-Moreno P, León-Cano A, Monje A, Ortega-Oller I, O'Valle $F$, Catena A. Abutment height influences the effect of platform switching on peri-implant marginal bone loss. Clin Oral Implants Res 2016;27:167-73.

Received October 8, 2018 Accepted January 21, 2019 